\title{
Petrographic Studies of Pb-Zn Ore Deposits of Rajpura-Dariba-Bethumni Belt in District Udaipur (Rajasthan) India
}

\author{
Juned Alam*, Farhat Nasim Siddiquie, Mohd Shaif \\ Department of Geology, Aligarh Muslim University, Aligarh, India \\ Email: ${ }^{*}$ juned.iit87@gmail.com
}

Received 19 March 2015; accepted 9 April 2015; published 13 April 2015

Copyright (C) 2015 by authors and Scientific Research Publishing Inc.

This work is licensed under the Creative Commons Attribution International License (CC BY). http://creativecommons.org/licenses/by/4.0/

(c) (i) Open Access

\section{Abstract}

The Proterozoic Aravalli-Delhi orogenic complex hosts a large number of economically important stratabound base metal sulphide deposits. In the present work, rock samples taken from Outcrop and Underground Mine of Sindeskar Kalan, Vedanta Group, Rajpura-Dariba-Bethumni Belt which are located at a distance of $76 \mathrm{Kms}$ from Udaipur District (Rajasthan) have been studied. The chief litho units of the group are identified which contain sulfide-bearing calc-silicate and graphite mica schist, dolomite marble, calc-biotite schist and quartzite. Importance to the ore minerals like galena and sphalerite which have been reported in association with the buffer minerals like pyrite and pyrrhotite occurr in the host rocks of the study area. Ore petrography denotes two types of sphalerites, 1) highly deformed and dark brown colour, 2) less deformed and with light yellow colour. Galena shows high reflectance and a network of triangular pits. Pyrite shows high reflectance and anomalous anisotropism because of high brittleness.

\section{Keywords}

Sphalerite, Galena, Pyrite, Zn-Pb Ores, Ore Textures, Rajpura-Dariba-Bethumni Belt, Udaipur District (Rajasthan)

\section{Introduction}

Zinc-Lead deposits of various sizes and grades occur throughout the belt in calc-silicate bearing dolomite and graphite mica schist horizons [1], the latter in general containing low-grade disseminated sulfides of large volumes. The ores from the various deposits in the belt have more or less similar mineral assemblage, differing

\footnotetext{
${ }^{*}$ Corresponding author.
} 
mainly in their relative proportions from deposit to deposit. The stratiform ore bodies [2] mainly comprised sphalerite, galena, chalcopyrite, and pyrite-pyrrhotite. The stratiform ores of Rajpura-Dariba are characterized by the presence of different verities of laminated sphalerite such as lemon yellow, light brown, and dark brown, a feature that is absent in other deposit in the belt.

The Archaean basement comprising of gneiss, schist, amphibolite, quartzite and granite dating back to 3.2 to 2.5 by showing unconformable relationship with the Aravalli cover rocks, is clearly marked in and around Udaipur. Stratigraphic succession, established by [3] for the Aravalli Supergroup of the type area around Udaipur and Zawar shows two major groups separated by an unconformity. The Upper Aravalli Group consists of greywacke-slate-phyllite, quartzite, dolomite and siltyarenite (host for sulphides of zinc and lead) while carbonaceous and pelitic phyllites, dolomite, quartzite, stromatolyte, phosphorite, chlorite schist, amphibolite, quartz arenite and local conglomerate [4] belong to Lower Aravalli Group. In general, Aravalli rocks in Udaipur region show a low-grade metamorphism. The recrystallisation of the silicate minerals suggests the grade of metamorphism to be of greenschist facies [5].

With the help of these works, the authors are trying to establish the petrography of $\mathrm{Pb}-\mathrm{Zn}$ ore deposits (under the reflected light microscopy) of Rajpura-Dariba-Bethumni Belt in district Udaipur (Rajasthan). The ore petrography of the study area is helpful to establish textural relation and paragenesis of the $\mathrm{Pb}-\mathrm{Zn}$ ore deposits and host rocks of this area (Figure 1).

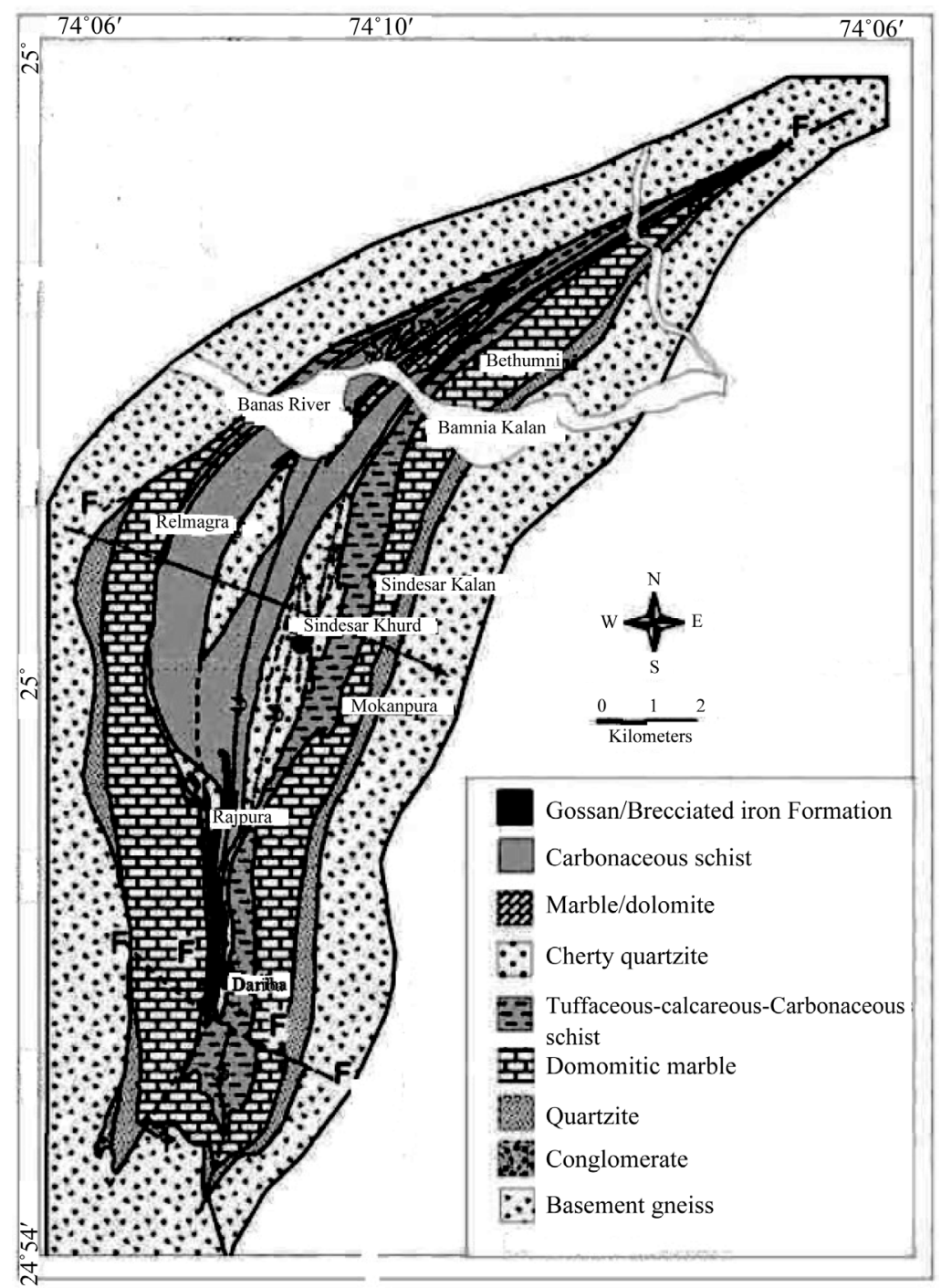

Figure 1. Regional geological map, Dariba Belt. Modified after [6]. 


\section{Geology}

The geology of Rajasthan has been studied by many workers [7]-[18] over decades and the different major geological units and prominent faults and lineaments of this region. The crust of the northwestern Indian Craton in Rajasthan comprises the Achaean Banded Gneissic Complex (BGC) forming the basement, overlain by the Proterozoic Delhi Aravalli Fold Belts of Delhi and Malani Igneous Suite, most of which are covered by the Tertiary and Quaternary sediments. Studies by [19] have provided constraints on the ages of the pre-Aravalli basement rocks. Detailed geological mapping by [20] suggests a wide variation in the spatial and temporal evolution of the region through different geodynamic processes.

The Aravalli mountain range in the northwest part of India extends over $700 \mathrm{~km}$ in length with a general NE-SW trend. It consists of two main Proterozoic sedimentary and volcano sedimentary successions, the Aravalli Supergroup and the Delhi Supergroup, respectively, which are bounded by the Great Boundary Fault to the east and the Western Marginal Fault to the west. These Proterozoic successions rest unconformably on Archean granitoid basement [21], commonly referred to as Banded Gneissic Complex/BGC [22]. The minimum age of the basement rocks is $2500 \mathrm{Ma}$ [23]. The Aravalli Supergroup, a sedimentary succession with minor volcanic flows near the base, developed as a cover sequence on the granitoid basement [21], the BGC of [22]. The existing geochronological data for the Aravalli Supergroupare insufficient to date precisely the opening and closure of the Aravalli Basin. However, the maximum age of the Aravalli Supergroup comes from the Sm-Nd systematics of the basal volcanic indicating $2326 \pm 321 \mathrm{Ma}$ [24] and the minimum age is considered to be $1900 \pm 80 \mathrm{Ma}$ from the Rb-Sr dating of Darwar Granite that was emplaced synkinematically with the earliest deformation of the Aravalli [25].

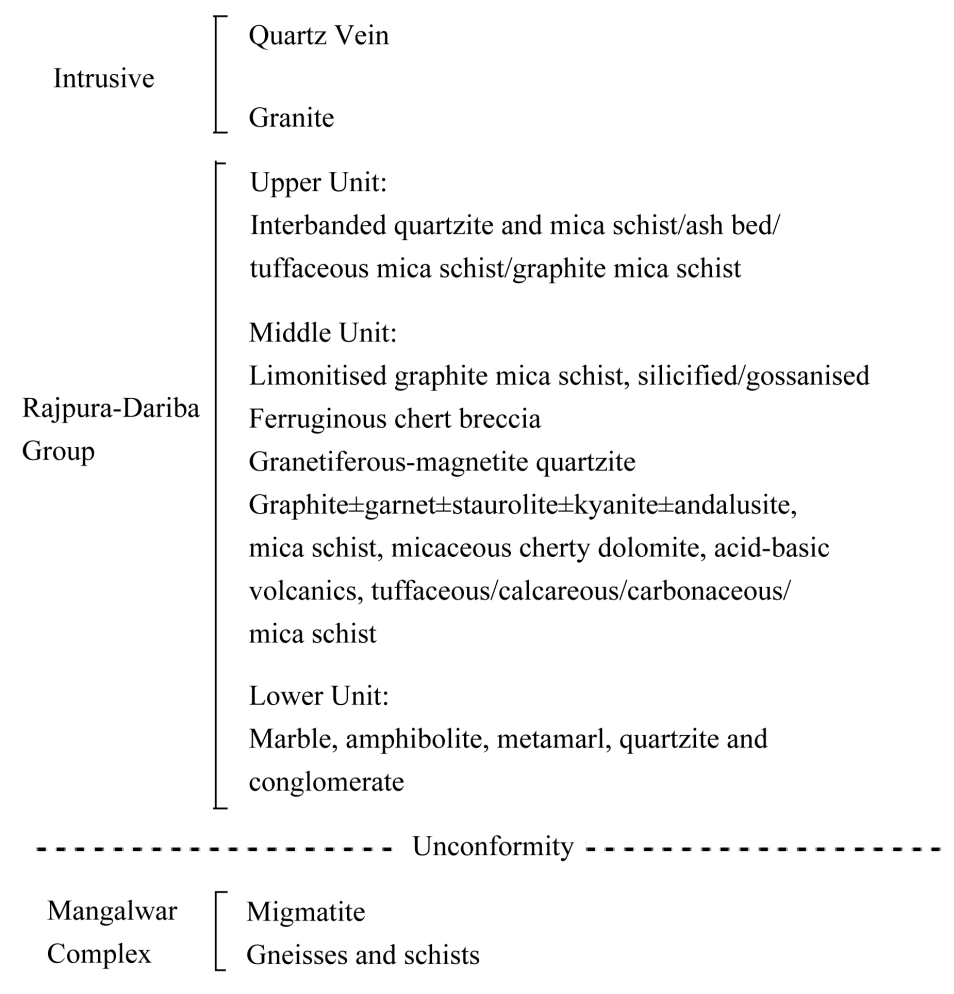

Stratigraphy of the study area [26].

\section{Material and Methods}

A total of 25 samples were collected from the different levels of underground mine as well as outcrop samples from the selected mine (both of ores and rocks) of the study area, out of which fresher and unweathered samples were selected for petrographic and ore petrographic studies of the thin section, polished section and doubly polished blocks of ores were carried out under transmitted and reflected light respectively. 


\section{Petrography of $\mathrm{Pb}-\mathrm{Zn}$ Ore}

\subsection{General Statement}

Ore microscopy is the traditional name for the study of opaque minerals using a polarizing 'incident light' microscopy [27]. Mineral identification is an important aspect of the study of the opaque ores. In the study area most opaque minerals are pyrite, galena, phyrrhotite, chalcopyrite and sphalerite (transparent to translucent). Pyrite shows high reflectance and brittleness, galena shows triangular pits and ductile nature. Mostly two types of sphalerite one is less disturb and second is highly disturb by tectonic activities. The main objective of this study was to identify the number of ore phases present in the sample and their mutual relationship with different gangue minerals, ore textures etc.

\subsection{Sphalerite}

Sphalerite occurs as dominant mineral of zinc ore deposit and it is occurs in various forms and assemblages throughout the belt. It occurs in association with galena, pyrite and phyrrhotite.Sphalerite occurs in two generations. The first generation is light brown in colour and less deformed (Figure 2), second is dark brown in colour and highly deformed (Figure 3).

\section{Optical Properties}

The colour of sphalerite under the microscope is dark brown to light brown (Figure 4) and some samples also show colourless. It is recognized by its low reflectance, weak pleochroism, transparent to translucent in nature,

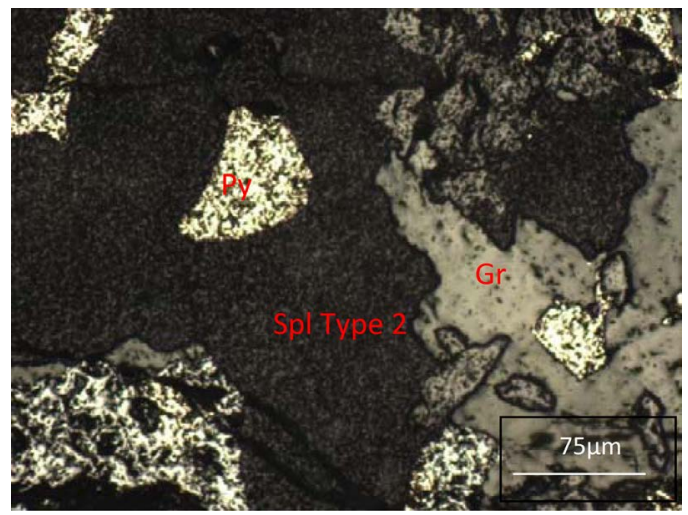

Figure 2. Fractured sphalerite with pyrite (yellow) and graphite Rajpura-Dariba-Bethumni Belt in District Udaipur (Rajasthan).

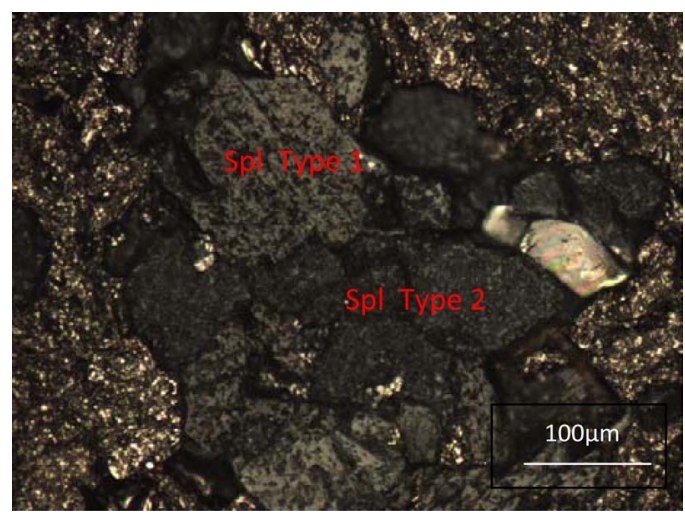

Figure 3. Two types of sphalerite, one is light brown and second is dark brown. Rajpura-Dariba-Bethumni Belt in District Udaipur (Rajasthan). 


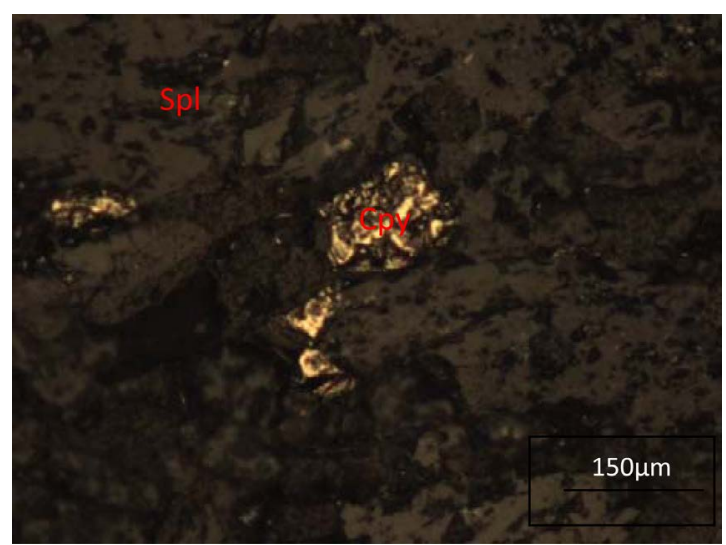

Figure 4. Chalcopyrite with Sphalerite which is showing golden yellow colour. Rajpura-Dariba-Bethumni Belt in District Udaipur (Rajasthan).

showing internal reflection, giving reddish brown or yellowish brown colour. Replacement textures are common. The grain size is variable, most of the individual grains are subhedral; some are elongated. The associated minerals are galena, pyrite, chalcopyrite and phyrrotite.

\subsection{Galena}

Galena is found in association with graphite mica schist (GMS) and dolomite (Figure 5).

\section{Optical Properties}

Under the microscope galena is white (bright) or colourless. It showed high reflectance than that of sphalerite (Figure 6). Granular aggregates and skeletal crystals are common, a perfect cubic cleavage is often noted. Triangular pits (Figure 7) are clearly seen due to its ductile in nature. It is associated with sphalerite and pyrite and show secondary alteration along cracks and cleavages. It is also showing mutual boundary texture and core replacement texture with sphalerite and pyrite.

\subsection{Pyrite}

Pyrite is also found in association with graphite mica schist (GMS) and dolomite throughout the belt. It is dominant mineral after sphalerite and galena in Rajpura-Dariba.

\section{Optical Properties}

This mineral is light yellow to brass yellow in colour. It is recognized by its high reflectance (Figure 8 and Figure 9), showing anomalous anisotropism, spherical aggregates i.e. framboids texture are developed. In the study area pyrite mainly associated with sphalerite, galena and chalcopyrite etc.

\subsection{Chalcopyrite}

Chalcopyrite is rare in the study area.

\section{Optical Properties}

Chalcopyrite is golden yellow in colour (Figure 4) which differentiates it from gold. It is recognized by its strongly anisotropic, showing polysynthetic twining.

\section{Results and Discussion}

\subsection{Microstructure/Texture}

The zinc and lead minerals of this area exhibit distinct textures due to the presence of different mineral association. The texture of ores are identified in polished block under the reflected light microscopy which are as follows: 


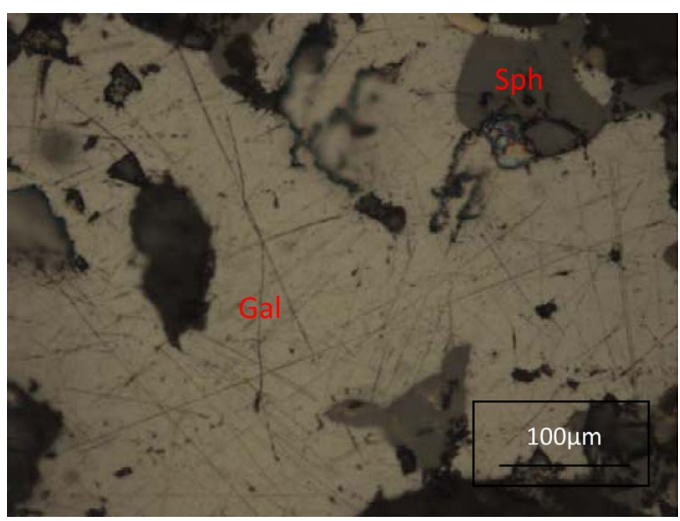

Figure 5. Galena with sphalerite showing deformed crystal. Rajpura-Dariba-Bethumni Belt in District Udaipur (Rajasthan).

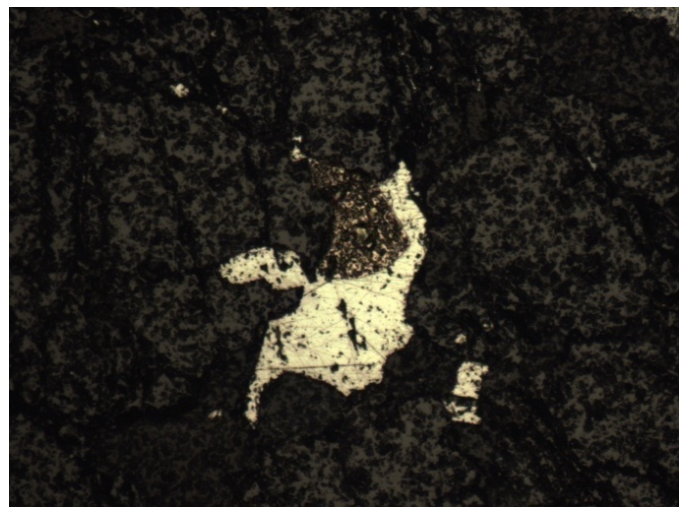

Figure 6. Mutual Boundary texture in galena and Sphalerite. Rajpura-Dariba-Bethumni Belt in District Udaipur (Rajasthan).

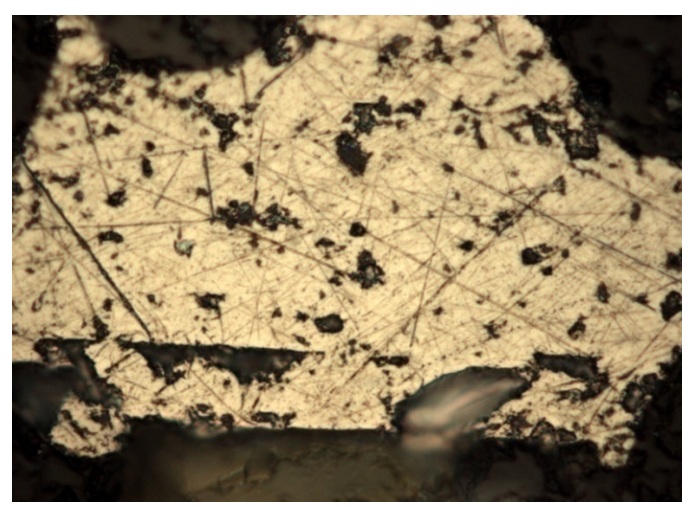

Figure 7. Galena showing triangular pits. RajpuraDariba-Bethumni Belt in District Udaipur, (Rajasthan).

- Replacements textures

Boarder replacement

Rim replacement

Core replacement

- Mutual boundary texture 


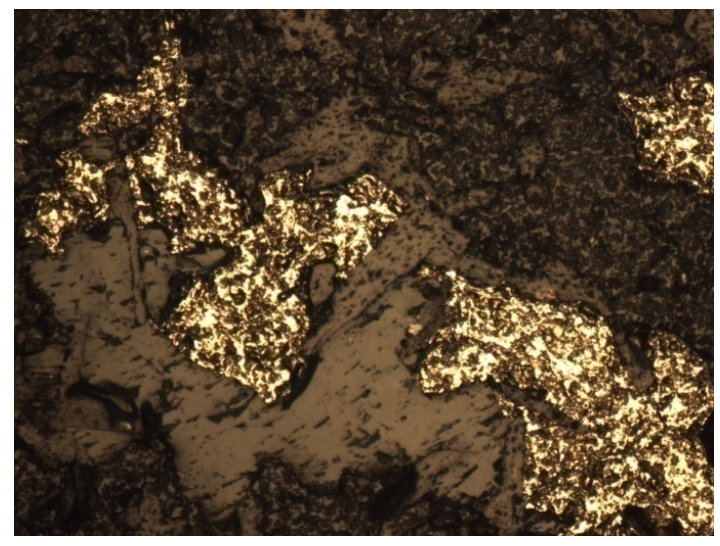

Figure 8. Mutual Boundary texture in pyrite and sphalerite. Rajpura-Dariba-Bethumni Belt in District Udaipur (Rajasthan).

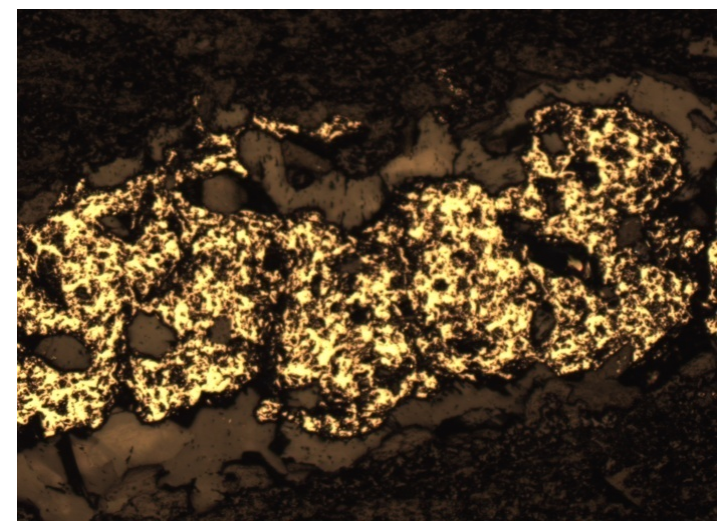

Figure 9. Rim replacement texture of pyrite by sphalerite. Rajpura-Dariba-Bethumni Belt in District Udaipur (Rajasthan).

- Fibrous texture

- Deformation texture

- Intergrowth texture

- Framboidal texture

\subsubsection{Replacements Textures}

Replacement texture is common in all minerals of this area and these replacement textures are observed between different mineral assemblages [27]. Replacement textures are formed between sphalerite-galena and sphaleritepyrite. There placement texture the early formed ore phases occurred along the fractures, fissures, grain boundaries, cleavage planes and at the core of the ore minerals.

\section{1) Rim or Border replacement texture}

This texture is mainly shown by pyrite and sphalerite ore minerals (Figure 9 and Figure 10).

\section{2) Core replacement texture}

Core replacement texture is shown mainly by sphalerite and pyrite where the centre of the ore mineral is completely or partially replaced (Figure 11 and Figure 12).

\subsubsection{Mutual Boundary Texture}

Mutual boundary (Figure 8) relations are seen between the minerals sphalerite and galena, sphalerite and pyrite. The contact between sphalerite with galena and pyrite are smooth have perfect boundary and there is no replacement between sphalerite with galena and pyrite. On the basis of their preferred orientation and mutual 


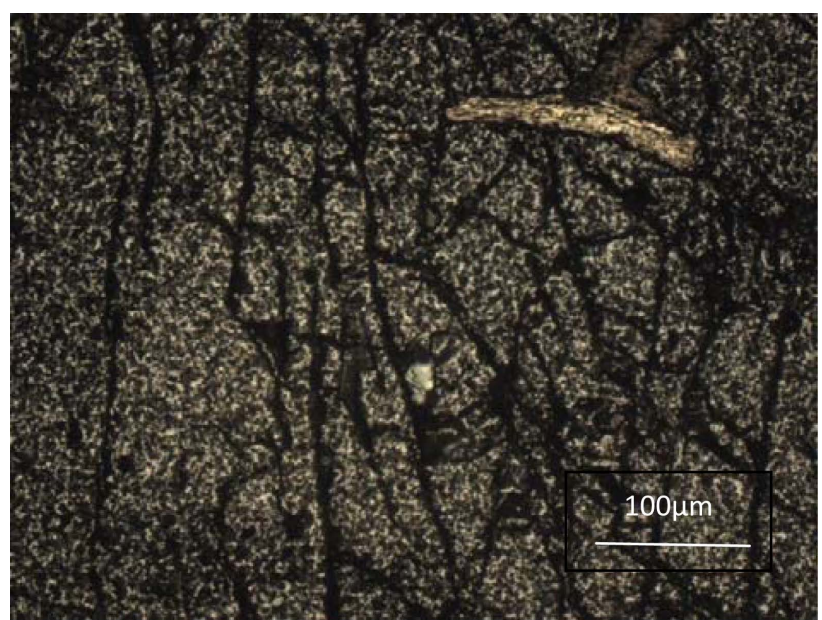

Figure 10. Border replacement texture in sphalerite. RajpuraDariba-Bethumni Belt in District Udaipur (Rajasthan).

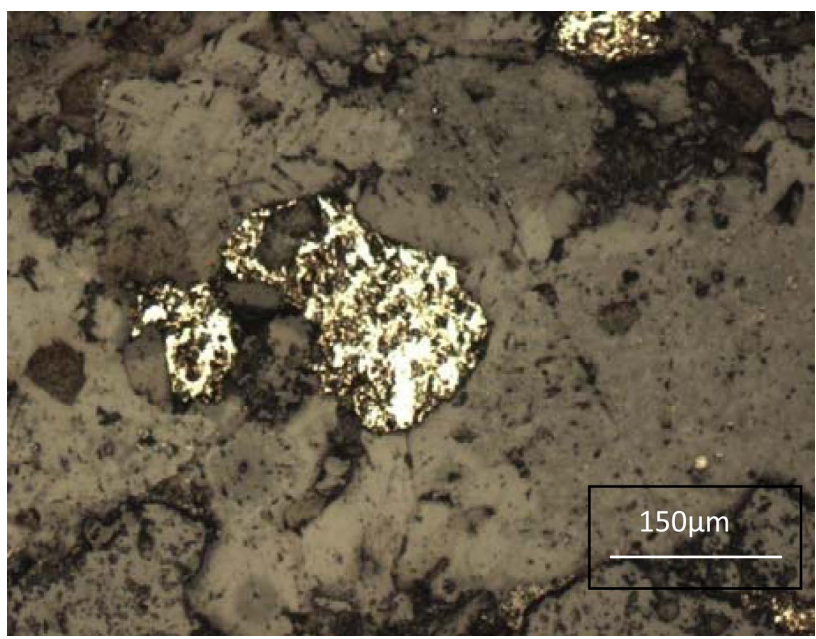

Figure 11. Core replacement texture by pyrite. Rajpura-DaribaBethumni Belt in District Udaipur (Rajasthan).

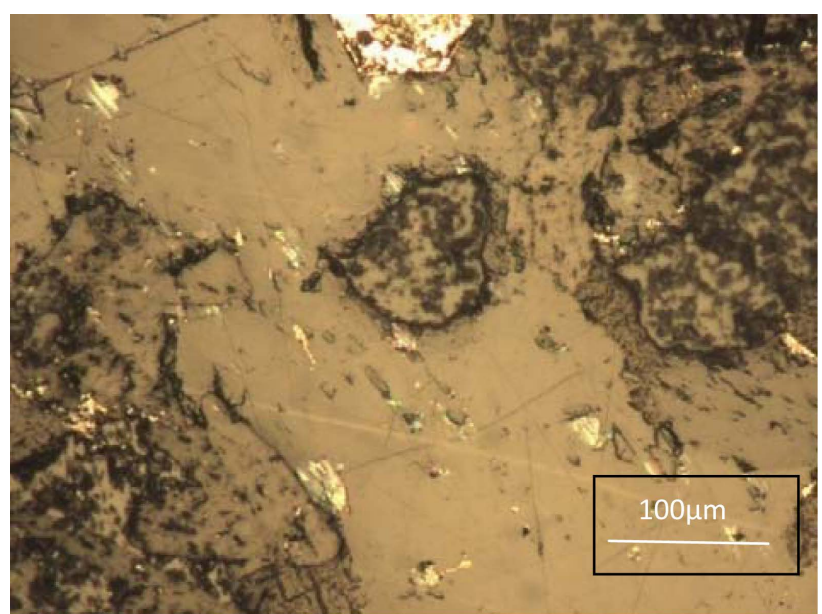

Figure 12. Core replacement texture by sphalerite. RajpuraDariba-Bethumni Belt in District Udaipur (Rajasthan). 
boundary relation, it is suggestive of simultaneous crystallization [28].

\subsubsection{Fibrous Texture}

Sphalerite forms concentric overgrowth sinward from a vein wall, radiating from multiple growth along the open fractures and sometimes acicular crystals of sphalerite are found radiating from a centre (Figure 13).

\subsubsection{Deformation Texture}

Some deformation are seen in galena may be due to micro-level deformation or due to local folding and faulting (Figure 5).

\subsubsection{Intergrowth Texture}

Some samples of ore minerals also showed intergrowth texture by sphalerite and galena.Suggested primary texture which is developed during the deposition of ore minerals (Figure 14).

\subsubsection{Framboidal Texture}

These are aggregates of spherical grains or particles. Pyrite shows this type of texture (Figure 15).

\section{Conclusions}

The present study of Rajpura-Dariba-Bethumni Belt, Udaipur District (Rajasthan), is on ore petrography of Pro-

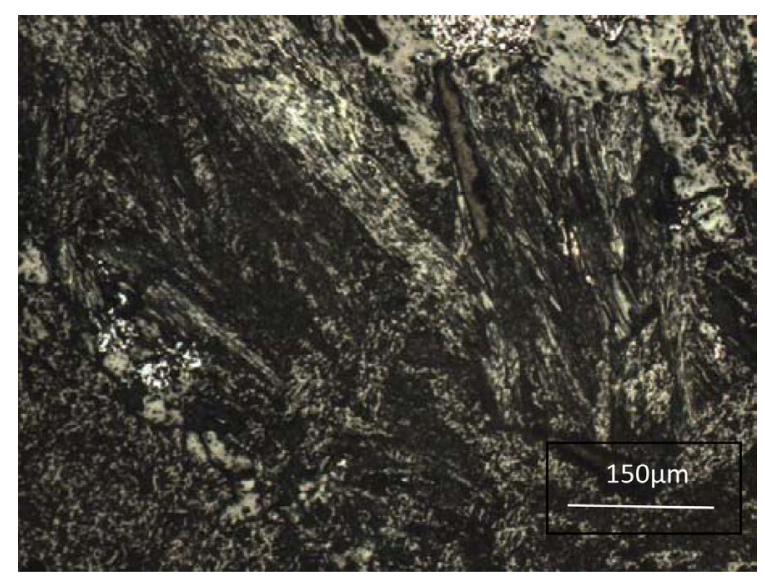

Figure 13. Fibrous texture in sphalerite. Rajpura-DaribaBethumni Belt in District Udaipur (Rajasthan).

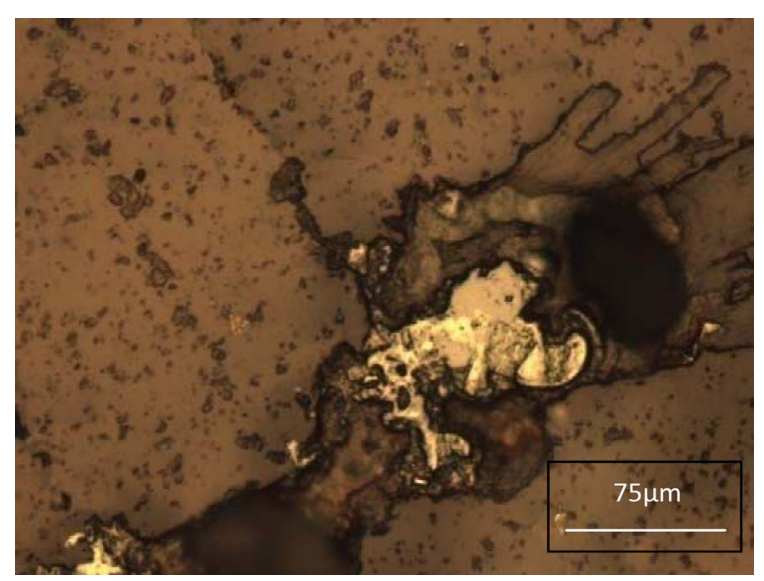

Figure 14. Intergrowth texture by galena in sphalerite Rajpura-Dariba-Bethumni Belt in District Udaipur (Rajasthan). 


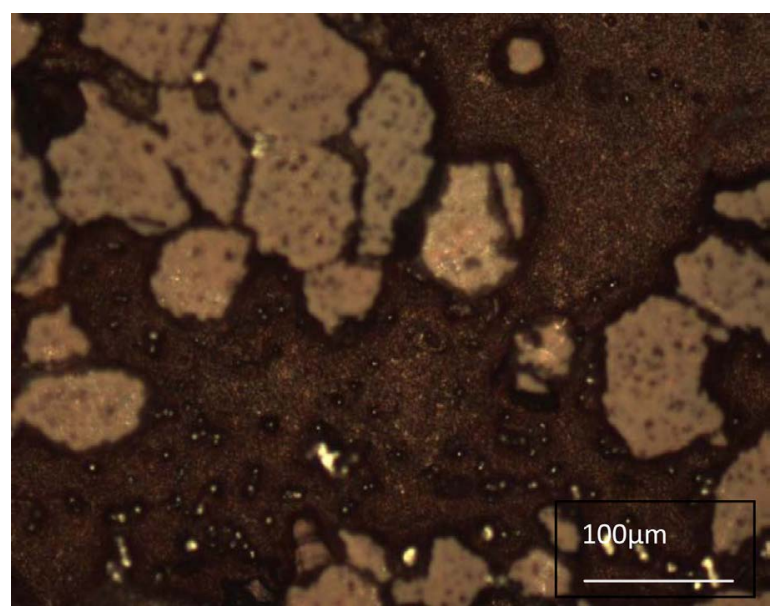

Figure 15. Framboidal texture showing by pyrite. RajpuraDariba-Bethumni Belt in District Udaipur (Rajasthan).

terozoic Carbonate hosted formation. This work involved the study of their ore-petrography and wafer thin section $(0.3 \mathrm{~mm})$ petrography. On the basis of above parameters the following discussion was made to bring out valuable conclusion at the end.

The Underground samples of ore minerals are dark brown in colour, which contain sulfide bearing predominantly chemogenic rocks, admixes with minor clastics, and are deposited under reducing euxinic condition in linear inland basin/trough. The metallogenic belt comprises assemblages of medium to high grade metavolcanosedimentry rocks equivalents of orthoquartzite, carbonates and caqrbonaceous facies metamorphosed to medium grade amphibolite facies belonging to the Middle Aravalli Group. Zink-Lead deposits of various sizes and grades occur through the belt in calc-silicate bearing dolomite and graphite mica schist horizone. The stratiform ore bodies mainly comprise sphalerite, galena, chalcopyrite, pyrite-pyrrhotite. Presences of pyrites indicate the reducing environment condition. Some calcites and lots of quartz veins/bands were also reported from the samples studied.

Therefore the presences and absences of pyrites could be one of the parameter which controls the chemical transformation that taking place in the inorganic matter substituent to depositions. The cementing material is mainly silica. The opaque minerals are mainly pyrites (Buffer mineral) which show yellow to white colour and high reflectance in reflected light microscopy, and are Pyritohedron, showing anomalous anisotropism and having brittle in nature. Galena shows white colour and high reflectance in reflected light microscopy, and also showing triangular pits and having ductile in nature and showing deformation texture. Two types of sphalerite, one is light brown colour and having less disturbed and another one is dark brown in colour and showing internal reflection, highly disturbed and fractured which indicate tectonic disturbance in the area. Some other minerals like pyrrhotite, chalcopyrite (golden colour) and graphite also present.

\section{Acknowledgements}

The authors are thankful to the Chairman, Department of Earth Science, Indian Institute of Technology, Bombay, Mumbai and also chairman of Department of Geology, Aligarh Muslim University, Aligarh For providing facilities to carry out the study.

\section{References}

[1] Chauhan, D.S. (1977) The Dariba Main Lode of the Rajpura-Dariba Zinc-Lead-Copper Belt, Udaipur District, Rajasthan. Journal of Geological Society of India, 18, 611-616.

[2] Deb, M., Banerjee, D.M. and Bhattacharya, A.K. (1978) Precambrian Stromatolite and Other Structures in the RajpuraDariba Polymetallic Ore Deposit, Rajasthan, India. Mineralium Deposita, 13, 1-9. http://dx.doi.org/10.1007/BF00202904

[3] Roy, A.B., Paliwal, B.S. and Goel, O.P. (1971) Superposed Folding in the Aravalli Rocks of the Type Area around Udaipur, Rajasthan. Journal of Geological Society of India, 12, 342-348. 
[4] Haldar, S.K. and Deb, M. (2001) Geology and Mineralization of Rajpura-Dariba Lead-Zinc Belt, Rajasthan. In: Deb., M. and Goodfellow, W.D., Eds., Sediment-Hosted Lead-Zink Deposit Modeling Program, Proceeding, Delhi-Udaipur, 10-17 December 2001, 177-187.

[5] Gupta, B.C. (1934) The Geology of Central Mewar. Memoir of Geological Society of India, 65, 107-168.

[6] Ameta, S., Das Gupta, S. and Sharma, B.B. (1999) Geology, Structure and Mineralisation in Dariba-Bethumni-Surawas Belt, Rajsamand Dist., Rajasthan. Records of the Geological Survey of India, 129, 22-24.

[7] Deb, M. and Sarkar, S.C. (1990) Proterozoic Tectonic Evolution and Metallogenesis in the Aravalli Delhi Orogenic Complex, Northwestern India. Precambrian Research, 46, 115-137. http://dx.doi.org/10.1016/0301-9268(90)90069-3

[8] Deb, M. (1982) Rare Minerals in Rajpura-Dariba Ores-Some Further Comments. Journal of Geological Society of India, 23, 253-260.

[9] Deb, M. and Kumar, R. (1982) The Volcano-Sedimentary Environment of Rajpura-Dariba Polymetallic Ore Deposit, Udaipur District, Rajasthan. Geological Survey of India, Symposium on Metallogeny of the Precambrian, IGCP Project 91, 1-17.

[10] Fareeduddin (1998) Single Zircon Age Constraints on the Evolution of Rajasthan Granulite. In: Paliwal, B.S., Ed., The Indian Precambrian, Scientific Publishers, Jodhpur, 547-556.

[11] Naha, K. and Majumdar, A. (1971) Reinterpretation of the Aravalli Basal Conglomerate at Morchana, Udaipur District, Rajasthan, Western India. Geological Magazine, 108, 111-114. http://dx.doi.org/10.1017/S0016756800051128

[12] Naha, K. and Halyburton, R.V. (1974) Early Precambrian Stratigraphy of Central and Southern Rajasthan, India. Precambrian Research, 1, 55-73. http://dx.doi.org/10.1016/0301-9268(74)90018-7

[13] Poddar, B.C. (1974) Evolution of Sedimentary Sulphide Rhythmites into Metamorphic Tectonites in the Base Metal Deposits of Rajpura-Dariba, Rajasthan. Golden Jubli Volume, Quarterly Journal of Geological Mineral Metamorphic Society of India, 46, 207-221.

[14] Poddar, B.C. and Mathur, R.K. (1965) A Note on the Repetitious Sequence of Grewacke-Slate-Phyllite in the Aravalli System around Udaipur, Rajasthan. Bulletin-Geological Society of India, 2, 83-87.

[15] Raja Rao, C.S. (1970) Sequence, Structure and Correlation of the Metasediments and Genesis of the Banded Gniessic Complex of Rajasthan. Record of Geological Survey of India, 98, 122-131.

[16] Ranawat, et al. (1988) Metamorphic Character of Rampura-Agucha Pb-Zn Deposit, Rajasthan. Memoir Geological Society India, 7, 397-409.

[17] Sharma, R.S. (1988) Patterns of Metamorphism in the Precambrian Rocks of the Aravalli Mountain Belt. Geological Society of India Memoir, 7, 33-75.

[18] Sinha-Roy, S. (1984) Precambrian Crustal Interaction in Rajasthan, NW India. Proceeding Seminar on Crustal Evolution of Indian Shield and Its Bearing on Metallogeny, Indian Journal of Earth Sciences, 84-91.

[19] Gopalan, K., Trivedi, J.R., Balasubramanyam, M.N., Roy, S.K. and Sastri, C.A. (1979) Rb-Sr Chronology of the Khetri Belt, Rajasthan. Journal of Geological Society of India, 20, 450-456.

[20] Roy, A.B. and Jakhar, S.R. (2002) Geology of Rajasthan (Northwest India): Precambrian to Recent. Scientific Publishers, India, $412 \mathrm{p}$.

[21] Roy, A.B. and Kroner, A. (1996) Single Zircon Evaporation Ages Constraining the Growth of the Archaean Aravalli Craton, Northwestern Indian Shield. Geological Magazine, 133, 333-342. http://dx.doi.org/10.1017/S0016756800009067

[22] Heron, A.M. (1953) Geology of Central Rajasthan. Mem. 79, Geol. Survey of India, 339 p.

[23] Wiedenbeck, M., Goswami, J.N. and Roy, A.B. (1996) Stabilization of the Aravalli Craton of the Northwestern India at 2.5 Ga: An Ion Microprobe Zircon Study. Chemical Geology, 129, 325-340. http://dx.doi.org/10.1016/0009-2541(95)00182-4

[24] Ahmad, T., Dragusanu, C. and Tanaka, T. (2008) Provenance of Proterozoic Basal Aravalli Mafic Volcanic Rocks from Rajasthan, Northwestern India: Nd Isotopes Evidence for Enriched Mantle Reservoirs. Precambrian Research, 162, 150-159. http://dx.doi.org/10.1016/j.precamres.2007.07.011

[25] Ray, J.N. (1980) An Evaluation of the Tectonic Framework of the Rampura-Agucha Zinc-Lead Deposit, Bhilwara District, Rajasthan. Indian Minerals, 34, 19-21.

[26] Gandhi, S.M. (2001) The Ancient Mining and Metallurgy in Rajasthan. Hindustan Zinc Limited, Vol. 4, 2-13.

[27] Ineson, P.R. (1989) Introduction to Practical Ore Microscopy. Longman Singapore Publishers Pvt. Ltd, Singapore, 181.

[28] Siddiquie, F.N. and Bhat, S.H. (2008) Mineragraphic Study of the Manganese Ores in Vizianagram Manganese Ores Belt (A.P.) India. Journal of the Indian Association of Sedimentologist, 27, 87-98. 